\title{
Comparative Analysis of Filtration Ability of Different Cloth Masks
} Farkı Kumaş Maskelerin Filtrasyon Özelliklerinin Karşılaşısımalı Analizi

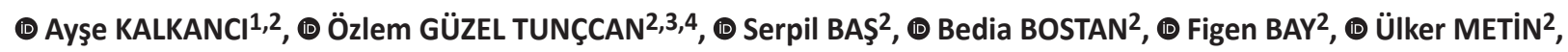 \\ (D) Pınar AYSERT YILDIZ2,4, (D) Selçuk ÖZGER ${ }^{2,4}$, (D) Murat DiZBAY2,4,5, (D) Mustafa Necmi ílhAN 6 \\ 1 Gazi University Faculty of Medicine, Department of Medical Microbiology, Ankara, Turkey \\ ${ }^{2}$ Gazi University Hospital, Infection Control Committee, Ankara, Turkey \\ ${ }^{3}$ Gazi University Faculty of Medicine, Ankara, Turkey \\ ${ }^{4}$ Gazi University Faculty of Medicine, Department of Infectious Diseases and Clinical Microbiology, Ankara, Turkey \\ 5 Gazi University, Health Research Application Center Gazi Hospital, Ankara, Turkey \\ ${ }^{6}$ Gazi University Faculty of Medicine, Department of Public Health Ankara, Turkey
}

\section{Abstract}

Introduction: The effectivity of cloth masks is one of the major concerns during pandemic. In this study, the filtration ability of different cloth masks was compared.

Materials and Methods: We examined the filtration ability of different cloth masks in "Touch Screen Aerosol Photometer" D0P3500 machine by testing 0,3-0,5 $\mu \mathrm{m}$ diameter standart "aerosol" particle at mask factory (MAKSAM) of Mechanical and Chemical Industry Company located in Ankara. In order to show the difference in filtration ability of the cloth maskes clearly, particule size was defined as $0,3-0,5 \mu \mathrm{m}$. Pure silk $100 \%$, $80 \%$ silk $+20 \%$ polyester, $100 \%$ satin, 100\% polyester, 100\% cotton, 100\% bamboo and 50\% cotton + 50\% polyester were compared. Cloth masks made from these materials were tested three times; before washing, after ten times washing and combined using with a medical mask.

Results: N95/FFP-2 respirator was used as a "positive control" with a filtration ability of 99.7\%. Measurable filtration ability of total particle counts was $18.2 \%$ of three layered medical mask. When we tested double medical mask, reduction of total particle counts reached to $31.6 \%$. According to our result, we conclude that wearing double medical mask is more protective than wearing a single medical mask. Measureable reduction of total particle counts were different for all tested cloth masks. Cloth masks were tested second time after 10 times washing. Un-washed cloth mask made from $80 \%$ silk $+20 \%$ polyester was found to be protective, however after ten times washing particle counts of the same mask reduced markedly. Measurable reduction of total particle counts were also reduced after ten times washing of cloth masks made from 100\% satin and 100\% polyester. The most efficient cloth mask for blocking particules was 100\% cotton after ten times washing.

Conclusion: Our study offers evidence in favor of synthetic and polyester materials are not suitable for cloth masks since their filtration ability is reduced after multiple washing. Instead, use of cotton masks is more preventive than the others because of its increased filtration ability after washing. Combined wearing of medical mask and cloth mask together resulted in increased efficacy of filtration ability of both masks. We conclude that, wearing double mask is more effective than wearing a single mask when we consider the actual status of the pandemic with widespread distribution of mutant viruses and the high number of infected individuals in the public.

Keywords: COVID-19, mask, cloth mask, efficiency testing

\section{Öz}

Giriş: Kumaş maskelerin etkinliği pandemi süresince en çok ilgi çeken konulardan biri olmuştur. Bu çalışmada farklı kumaş maskeler filtrasyon özellikleri açısından karşılaştırılmıştır.

Gereç ve Yöntem: Bu çalışmada, farklı kumaş maskelerin partikül tutma yüzdesi (verimliliği) Makine Kimya Endüstrisi Kurumu Makine Maske Fabrikası laboratuvarında 0,3-0,5 m'lik standart "aerosol" partikül üreten "Touch Screen Aerosol Photometer" DOP3500 kullanılarak ölçülmüştür. Partikül büyüklüğü 0,3-0,5 m olarak tercih edilmiştir. Saf ipek, \%80 ipek + \%20 polyesterden üretilmiş kumaş, \%100 saten kumaş, \%100 polyester, \%100 pamuklu kumaş, \%100 bambu ve tıbbi önlük ve forma için kullanılan \%50 polyester + \%50 pamuklu (alpaka) kumaş karşılaştırılmıştır. Bu

Cite this article as: Kalkancı A, Güzel Tunçcan Ö, Baş S, Bostan B, Bay F, Metin Ü, Aysert Yıldız P, Özger S, Dizbay M, İlhan MN. Comparative Analysis of Filtration Ability of Different Cloth Masks. Mediterr J Infect Microb Antimicrob. 2021;10:25. 
kumaşlardan hazırlanan maskeler yıkanmadan önce, on kez yıkandıktan sonra ve üzerine tıbbi maske takarak toplam üç kez test edilmiş ve sonuçlar karşılaştırılmıştır.

Bulgular: Karşılaştırma için aerosol partikülleri \%99,7 oranında yakalayan N95/FFP-2 respiratörü "pozitif kontrol" olarak kullanılmıştır. Üç katlı tıbbi maske aerosol partiküllerin \%18,2'sini yakalamıştır. İki adet tıbbi maske üst üste takıldığında partikül yakalama yüzdesi \%31,6'ya yükselmiştir. Bu sonuca göre iki adet tıbbi maskeyi üst üste takmanın, tek maske takmaktan daha güvenli olduğu gösterilmiştir. Test edilen kumaşlar aerosol partikülleri farklı oranlarda tutabilmiştir. Kumaş maskeler 10 kez yıkandıktan sonra tekrar test edilmiştir. Yıkanmadan önce güvenli bulunan \%80 ipek + \%20 polyesterden üretilmiş kumaşın, yıkandıktan sonra tutucu özelliği belirgin azalmıştır. Yıkama sonrasında verimliliği azalan diğer kumaşlar saten kumaş ve \%100 polyester kumaşlardır. Yıkanma sonrası en güvenli kumaş ise \%100 pamuklu kumaş olarak belirlenmiştir.

Sonuç: Yıkama ile partikül tutma özelliği belirgin olarak azalan polyester veya sentetik kumaşların maske için uygun olmadığı, yıkamaya dayanıklı olup, verimliliği azalmayan, aksine artan pamuklu kumaşların maske olarak kullanılmasının daha güvenilir olduğu sonucuna varılmıştır. Tıbbi maskenin, kumaş maske üzerine takılması, tüm maskelerde partikül tutma yüzdesini, yani verimliliğini belirgin olarak arttırmıştır. Pandeminin eriştiği noktada, çok daha bulaşıcı olan mutant virüsler ve toplumda enfekte kişi sayısının artışı göz önüne alındığında, çift maske takmanın, tek maskeden daha güvenli olacağı sonucuna varılmıştır.

Anahtar Kelimeler: COVID-19, maske, kumaş maske, etkinlik testi

\section{Introduction}

The use of masks, frequent hand washing and protection of social distance are the recommended rules to prevent the distribution of all microorganisms transmitted through the respiratory tract in the society. The use of masks is valid for medical conditions that require "droplet isolation". The World Health Organization (WHO) declared a pandemic on March 12 , 2020, due to the emergence of a disease that the population had not been exposed to before, the transmission of the agent of the disease to humans and causing a dangerous disease, and the spread of the disease factor easily and continuously among people ${ }^{[1]}$. The agent of Coronavirus disease-2019 (COVID-19) was defined as severe acute respiratory syndrome coronavirus-2 (SARS-CoV-2), referring to the year the disease emerged and the picture it created ${ }^{[2]}$. During the pandemic period, the mask became the "pandemic symbol" as the most basic personal protective equipment. In this period, the use of masks in the society is more important than the use of masks by healthcare professionals ${ }^{[3]}$. Face masks are divided into textile (cloth/fabric) masks and medical face masks (medical/surgical). While medical masks are used in health institutions, masks made of different fabrics are widely used by both healthcare professionals and people living in the community. Medical masks and fabric masks prevent the scattering of respiratory droplets larger than $3 \mu \mathrm{m}$. Medical masks are produced in accordance with the European standard 14683 (European Norm, EN 14683). According to this standard, medical masks are made of non-woven fabric. The raw material of this non-woven fabric is polypropylene. In addition, polystyrene, polyethylene and polyester fabric can be used as raw materials. "Spunbond non-woven" fabric and "meltblown non-woven" fabric, which we often hear during the pandemic period, are essentially two separate non-woven fabric production techniques. Medical masks should consist of three layers, namely "polypropylene spunbond non-woven" fabric on the outermost layer, "polypropylene meltblown non-woven fabric" in the middle layer and "polypropylene spunbond nonwoven" fabric on the innermost layer. Medical masks produced in accordance with EN 14683 are expected to have a "bacterial filtration efficiency, (\%)" of at least $95 \%$ and a differential pressure $\left(\mathrm{Pa} / \mathrm{cm}^{2}\right)$ less than 40 , as specified in the standard. In addition, the biological load amount of all masks in terms of microbial cleaning should be less than 30 colony forming units $(\mathrm{CFU})^{[4]}$.

Until recently, there was no standard for fabric masks. On April 13, 2020, Centers for Disease Control and Prevention (CDC) published a guide for the preparation of fabric masks. In this guide, the method of preparing masks from cotton fabrics, old t-shirts and bandanas at home is described with figures ${ }^{[5]}$. In the document published by WHO for fabric masks, it was recommended that the mask should be at least 3 layers with a fabric containing hydrophilic material in the innermost part and hydrophobic material in the outer and middle parts ${ }^{[6]}$. On May 11, 2020, the "Standard for washable cloth mask" certificate was issued by the Ministry of Industry and Technology and the Turkish Standards Institute. According to this standard, the cloth mask must meet the TSE K 599 standard after at least 5 washes, that is, it can hold more than $90 \%$ of the particles larger than $3 \mu \mathrm{m}$, the breathability rate should be less than $60 \%$, and the microbial cleaning feature should be less than $30 \%$. According to the standard, this fabric production can be woven, knitted, knitwear or non-woven ${ }^{[7]}$. There are cotton and synthetic textile masks sold commercially in our country. In the period when the pandemic started immediately, Gazi Hospital Infection Control Committee sewed cloth masks made of alpaca fabric in the hospital tailoring and distributed to the services for the use of the healthcare personnel in the units that did not follow the COVID-19 patients. Considering that the pandemic 
and the recommendation for use of masks will continue, it is understood that it will be beneficial to increase the use of the cloth mask especially in the society.

The aim of this study was to examine the ability of fabric masks prepared from different fabrics to capture particles of 0.3-0.5 $\mu \mathrm{m}$ in "aerosol" size, compare different fabrics, determine the safest fabric, show the effect of multiple washing on the particle retention rate and to show whether using a cloth mask with a medical mask was superior to using one mask in capturing particles.

\section{Materials and Methods}

Masks

Seven different materials were selected, the fabric content of which was 100\% pure silk, $80 \%$ silk + 20\% polyester, 100\% satin, 100\% polyester, 100\% cotton, 100\% bamboo and 50\% polyester $+50 \%$ cotton (apron fabric, alpaca). Two-layer masks were sewn from these fabrics. The 50\% polyester $+50 \%$ cotton fabric mask known as "alpaca" was prepared only in a single layer. The masks used are shown in Picture 1.

A three-layer medical mask with polypropylene "spunbond nonwoven" fabric on the inner layer, polypropylene "meltblown nonwoven" fabric in the middle layer and polypropylene "spunbond non-woven" fabric on the outer layer was chosen as a medical (surgical) mask, manufactured and controlled according to EN 14683 standard.

Fabric masks were tested for particle permeability three times in total: Before washing, after washing 10 times and while using with the surgical mask (EN 14683 document can be accessed as an additional document). The superiority of fabrics to each other, the effect of washing and the superiority of the use of double masks to a single mask were presented in the results.

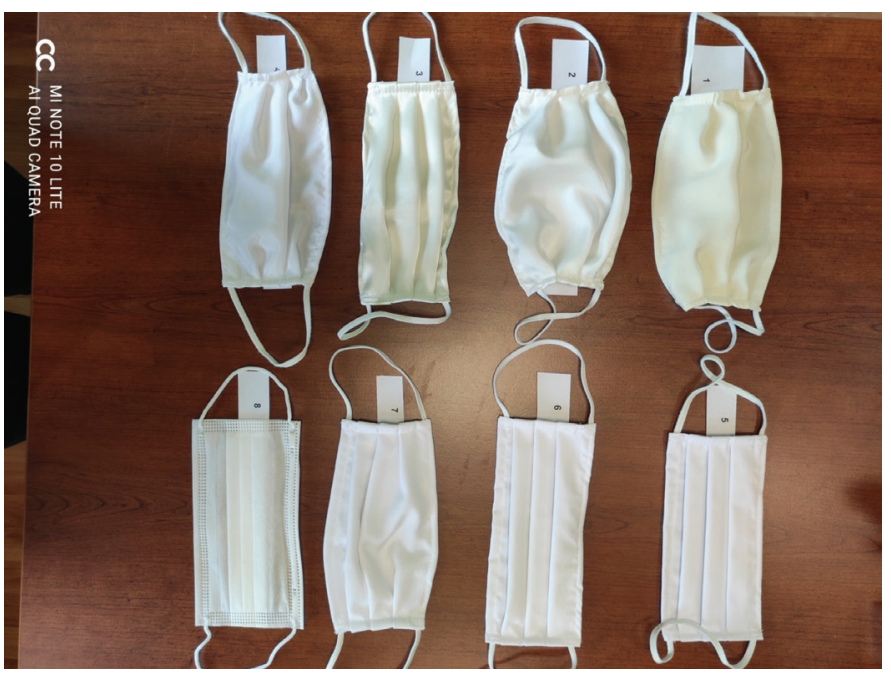

Picture 1. Cloth masks used in the study
The washing process was applied in $40{ }^{\circ} \mathrm{C}$ water for 50 minutes with standard laundry detergent without using chemicals. As a control of the percentage of aerosol capture, N95/FFP-2 masks called respirators, which should retain aerosol-sized particles at least 95\%, were used.

\section{Particle Permeability Test}

The tests were carried out in the laboratories of the Machinery Chemical Industry Corporation Maksam Machinery and Mask Factory. Particle permeability was tested on the "DOP3500" model of the "Touch Screen Aerosol Photometer". With a density of 6.6-8.5 mg/m $\mathrm{m}^{3}$ paraffin oil, 0.3-0.5 $\mu \mathrm{m}$ particles called "aerosol" were produced and sprayed on the mask surface. The particle retention percentage of the mask, ie the "efficiency" result, was recorded. The device was ISO 14644-3 approved and was used as a standard method in permeability tests applied on masks. If desired, it had the capacity to form particles in the size of 0.05-1.0 $\mu \mathrm{m}$. In this study, in order to show whether there was a significant difference in terms of permeability between the masks, particles with a size of 0.3-0.5 $\mu \mathrm{m}$ were preferred. The ability of fabric masks and medical masks to catch droplets larger than $3 \mu \mathrm{m}$ was considered sufficient.

\section{Statistical Analysis}

Four-well tables (Two by two), available at "https://www. openepi.com/TwobyTwo/TwobyTwo.htm" were used to compare the particle capture percentages of the masks. In calculating statistical significance, Pearson's chi-square test for particle permeability values $>25$, Yates chi-square test for values between 5-25 and Fisher's Exact test for values $<5$ were used. A value of $p<0.05$ was accepted for statistical significance.

\section{Results}

The particle retention percentage (efficiency) of the fabric masks was measured with a medical mask of known effectiveness and a respirator (N95/FFP-2) manufactured according to standards. For the tested 0.3-0.5 $\mathrm{mm}$ aerosol particles, N95/FFP-2 was accepted as "positive control". Manufactured according to the EN-149 standard of a known brand, the N95/FFP-2 respirator retained $99.7 \%$ of the particles. The three-layer medical mask made according to the EN 14683 standard captured $18.2 \%$ of the aerosol particles. When two pieces of the same medical mask were worn, the particle capture percentage increased to $31.6 \%$. According to this result, it was shown that wearing two medical masks on top of each other was safer than wearing a single mask.

The tested fabrics were able to retain the aerosol particles in different proportions. Before washing, pure silk captured 9.1\% of $0.3-0.5 \mu \mathrm{m}$ aerosol particles, $80 \%$ silk $+20 \%$ polyester fabric 
mask 53.5\%, 100\% satin fabric mask 7.8\%, 100\% polyester fabric mask 51.9\%, 100\% cotton fabric mask 26.2\%, 100\% bamboo fabric mask $30.5 \%$, and $50 \%$ polyester $+50 \%$ cotton used for medical gowns and jerseys ( alpaca) fabric mask was able to capture $14.7 \%$ of the particles. The safest unwashed fabric was found to be the fabric made of $80 \%$ silk $+20 \%$ polyester.

The same fabric masks were tested again after 10 washes. Pure silk was able to hold $15.5 \%$ of the particles this time. After washing the fabric mask with $80 \%$ silk $+20 \%$ polyester captured $14.5 \%$ of the particles, $100 \%$ satin fabric mask $5.1 \%$, $100 \%$ polyester fabric mask 7.6\%, 100\% cotton fabric mask $46.1 \%, 100 \%$ bamboo fabric mask $41.1 \%$, and $50 \%$ polyester + $50 \%$ cotton (alpaca) fabric mask 32.6\%. Fabrics that increased efficiency with washing were pure silk, 100\% cotton, 100\% bamboo, and 50\% polyester + 50\% cotton apron alpaca fabric. Fabrics that decreased efficiency after washing were fabric made of $80 \%$ silk $+20 \%$ polyester, satin fabric and $100 \%$ polyester fabrics. The safest fabrics after washing were $100 \%$ cotton fabric, 100\% bamboo, and 50\% polyester + 50\% cotton alpaca fabric, respectively.

In the third step of the study, the same masks were tested, this time by wearing them together with medical masks. When pure silk masks were used together with the medical mask, $16.2 \%$ of the particles were caught by the masks. This ratio was $55.1 \%$ for $80 \%$ silk + 20\% polyester, $21.1 \%$ for $100 \%$ satin, $59.3 \%$ for $100 \%$ polyester, $31.1 \%$ for $100 \%$ cotton, $30.5 \%$ for $100 \%$ bamboo, and 35.8\% for Alpaca fabric which was 50\% polyester $+50 \%$ cotton, when used with medical mask. Wearing the medical mask on the fabric mask significantly increased the particle retention percentage (efficiency) in all masks. Wearing the fabric mask also increased the efficiency of the medical mask. All results of the study are presented in Tables 1 and 2, and Figures 1 and 2.

Table 1. Efficiency percentages of unwashed and 10 times washed masks

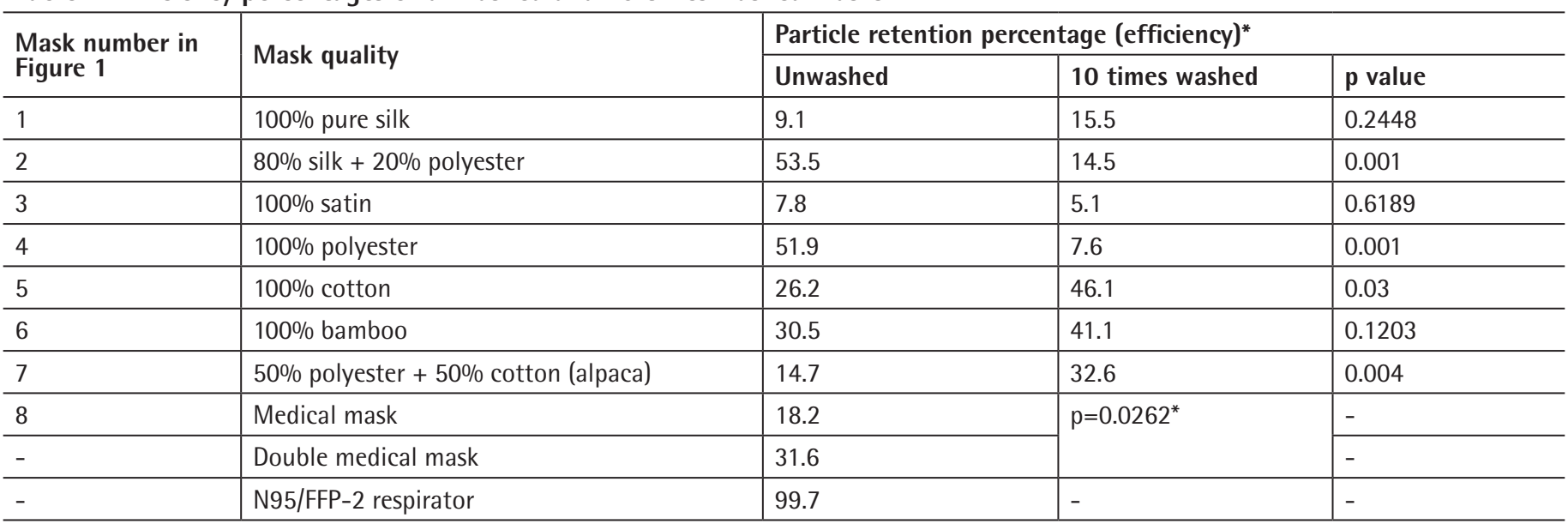

${ }^{*} \mathrm{p}=0.0262$ value belongs to single and double medical mask comparison

Table 2. Filtration ability of total particle counts of cloth masks before washing and combined using with a medical mask

\begin{tabular}{l|l|l|l|l}
\hline \multirow{2}{*}{$\begin{array}{l}\text { Mask number in } \\
\text { Figure 1 }\end{array}$} & Mask quality & \multicolumn{3}{l}{ Particle retention percentage (efficiency) } \\
\cline { 3 - 5 } & & Unwashed & $\begin{array}{l}\text { Unwashed (worn together with } \\
\text { medical mask) }\end{array}$ & p value \\
\hline 1 & $100 \%$ pure silk & 9.1 & 16.2 & 0.196 \\
\hline 2 & $80 \%$ silk + 20\% polyester & 53.5 & 55.1 & 0.81 \\
\hline 3 & $100 \%$ satin & 7.8 & 21.1 & 0.013 \\
\hline 4 & $100 \%$ polyester & 51.9 & 59.3 & 0.2952 \\
\hline 5 & $100 \%$ cotton & 26.2 & 31.1 & 0.4517 \\
\hline 6 & $100 \%$ bamboo & 30.5 & 30.5 & 1 \\
\hline 7 & $50 \%$ polyester + 50\% cotton (alpaca) & 14.7 & 35.8 & \\
\hline 8 & Medical mask & 18.2 & $\mathrm{p}=0.0262^{*}$ & \\
\hline- & Double medical mask & 31.6 & & \\
\hline- & N95/FFP-2 respirator & 99.7 & - & \\
\hline
\end{tabular}

${ }^{*} \mathrm{p}=0.0262$ value belongs to single and double medical mask comparison 


\section{Discussion}

One of the methods to control the spread of a respiratory pandemic factor is to wear a mask by everyone in the society ${ }^{[8]}$. Maintaining social distance, frequent hand washing, vaccination if available, and reducing social mobility are other control methods. Disposable surgical masks are preferred during the execution of the service in health institutions. In the community, fabric/cloth masks that can be washed multiple times are recommended as well as surgical masks ${ }^{[4-7]}$. It is difficult to check the safety of fabric masks. In the pandemic conditions we are in, besides commercially sold fabric masks,

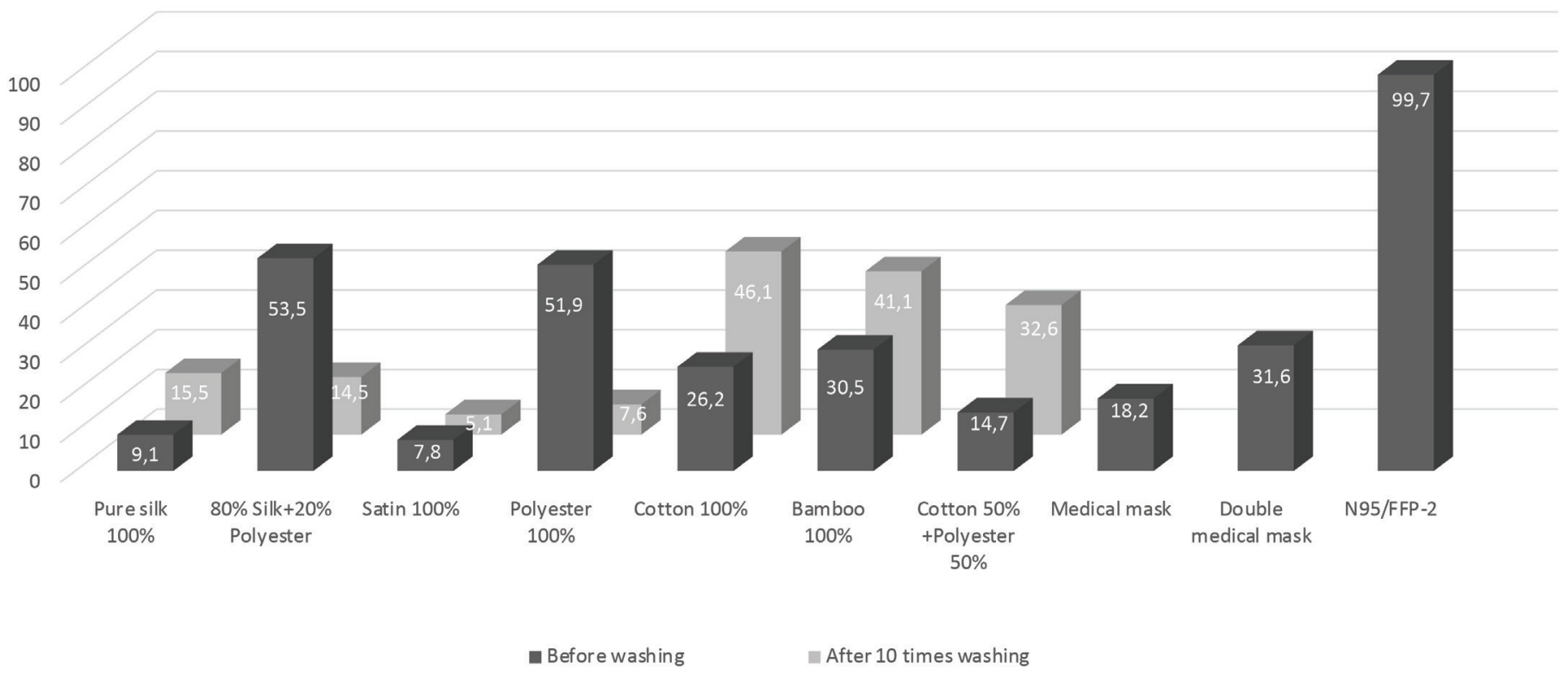

Figure 1. Filtration ability of total particle counts of cloth masks before washing and after ten times washing

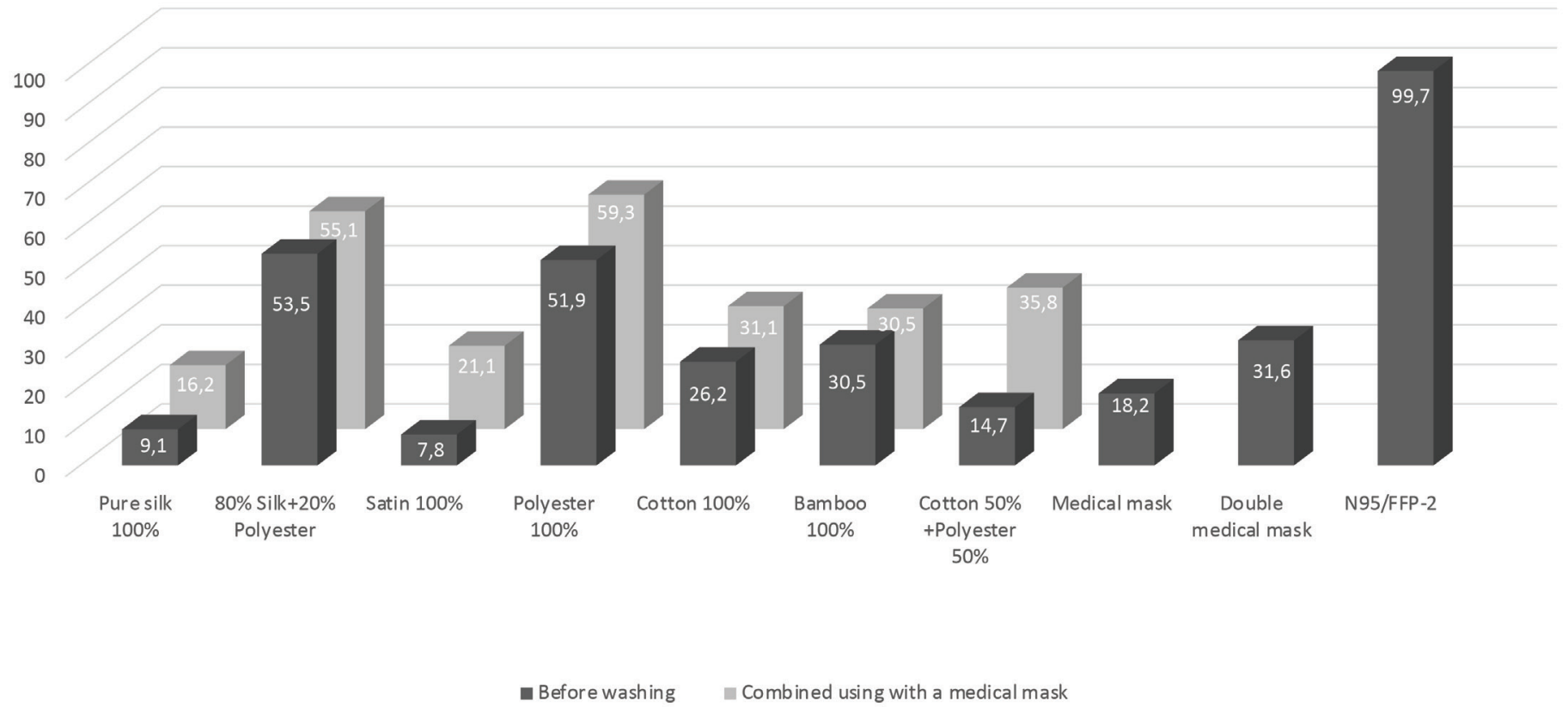

Figure 2. Filtration ability of total particle counts of cloth masks before washing and combined using with a medical mask 
masks made by individuals are also used. Considering that the pandemic will continue for a while, it is thought that knowing the particle retention properties of fabric masks can be effective in material selection and create scientific evidence to make suggestions to health authorities. Therefore, this experimental work was carried out. In our study, the particle retention feature of the fabric mask made of $80 \%$ silk $+20 \%$ polyester, which was found safe before washing, significantly decreased after washing. Washing significantly reduces the particle retention feature of polyester. For this reason, it has been observed that synthetic fabrics containing polyester are not suitable for masks. Considering that medical masks contain raw materials such as polystyrene and polyester, it can be interpreted that it is not suitable to be washed and used repeatedly. Fabric masks must be resistant to multiple washes. It was found in this study that the safest fabrics after washing were cotton fabrics. In addition, the efficiency of the disposable medical mask worn over the fabric mask increased significantly. At the point where the pandemic reached, it was concluded that wearing a double mask could be safer than a single mask, given the more contagious mutants and the increase in the number of infected people in the community. A similar recommendation was made by the $C D C$, the disease control and prevention center in the United States ${ }^{[0]}$. It has been recommended to wear a fabric mask over a disposable medical mask. In our study, it has been shown that efficiency increases when two disposable medical masks are worn on top of each other. However, the most important point to be considered here is when two masks are worn they must fit on the face. In the review of Darby et al. ${ }^{[8]}$, it was stated that the effectiveness of the mask depended on the fabric quality as well as the fit on the face. In the recommendation made by the CDC on February 10, 2021, it was especially emphasized that the mask should fit on the face ${ }^{[9]}$.

Different institutions and organizations all over the world have prepared original research and reviews showing the importance of the mask in pandemic control. In one of the most comprehensive reviews written on masks during the pandemic period, it was stated that the use of masks was the most effective method to control the pandemic at its source ${ }^{[10]}$. Numerous articles supporting the use of masks have been published ${ }^{[1]}$. Among them, some are about which fabric mask is more protective. The effects of fabric masks on protection from SARS-CoV-2 were reviewed, and it was stated that the most effective fabric ingredient was cotton-silk, cotton-chiffon, and cotton-flannel[ ${ }^{[12]}$.

Rengasamy et al. ${ }^{[13]}$ evaluated fabric masks during the 2009 $\mathrm{H} 1 \mathrm{~N} 1$ pandemic and compared the clothing such as t-shirts, towels and scarves with face masks according to their weaving content and weather resistance properties. As a result of the study, they showed that the clothes hold different percentages of particles between $40 \%$ and $90 \%$. Cotton towels were found to hold the most particles, but the air resistance was also found to be high, therefore, it was stated that it was not practical to use them as a mask.

During the COVID-19 pandemic period, many studies have been carried out on fabric masks. In one of these, Ho et al. ${ }^{[14]}$ compared surgical masks with cotton mask and showed that there was no difference between them in terms of protection. In this study, the particles scattered into the air behind the mask were counted. The method of counting airborne particles is not a method used in mask efficacy tests. In another current article, Fischer et al. ${ }^{[15]}$ developed a box that they presented as an "inexpensive method". The box had a hole. People who wore fabric masks made of different materials were made talking through this hole and the particles sent into the box were counted with a smart camera system. Although the method was not a standard method, it was shown that the least number of particles were dispersed orally when cotton/polyester blend masks and subsequently cotton masks were worn. In contrast, Swain ID recommended moisture testing as a "home testing method", stating that the fabric mask was not protective ${ }^{[16]}$. Because the methods are different, the results also vary.

Mask tests have been carried out since the $1970 \mathrm{~s}^{[17]}$. Before concluding that one product is more protective than another, it should be questioned which test is used. Researches using very different methods on mask effectiveness have been published. However, these methods are not standard. The effect value of the comparisons made without using the standard method is also controversial. For example, using the "smoke test", Douglas et al. ${ }^{[18]}$ stated that surgical masks did not capture "smoke-sized" particles and recommended that all healthcare professionals should use N-99/FFP3 equipment called respirators in all their contacts with COVID-19 patients. However, this proposal not compatible with both the recommendations of other international standard organizations and Turkish Ministry of Health guidelines. Patients with COVID-19 can only emit aerosol particles of 0.3-0.5 $\mu \mathrm{m}$ in size under certain conditions. These conditions are defined as tracheal intubation, nebulizer therapy, open airway aspiration, tracheostomy, bronchoscopy, cardiopulmonary resuscitation, endoscopy, respiratory tract sampling, and all kinds of gastroscopic and endoscopic procedures. Apart from the procedures that create aerosol, wearing a surgical mask is sufficient in healthcare ${ }^{[19]}$.

It is already known that fabric masks and medical masks cannot capture "nano" sized particles. However, this is not the purpose. Medical masks and fabric masks trap particles that are dispersed from the wearer. For this reason, the effectiveness of the masks to capture the particles coming out of the mouth, not the particles coming into the mask, should be tested ${ }^{[20]}$. 
The effectiveness tests of the masks have been standardized by the Turkish Standards Institute on the basis of the tests in European Norms. The TS EN $149+$ A1 test includes the subject of "respiratory protective devices - filtered half masks for protection against particles - features, experiments and marking". This test includes particle sizes, how the particle will be ejected and retained. TS EN 14683 certificate is also under the heading of "surgical masks - properties and test methods". In our study, an "aerosol photometer" device used in Machinery Chemical Industry laboratories and producing standard sized particles was used. Therefore, the scientific evidence level of our results is high.

In an article using standard methods, the researchers measured the knot number, permeability resistance and particle retention feature of the fabric in their studies using the "EN 1822" and "ISO 29463" filtration tests with $\mathrm{NaCl}$ particles. As a result of that study, 100\% cotton fabric was found to be at least 30\% effective ${ }^{[21]}$. This study is similar to our study in terms of method and results. In our study, it was shown that masks sewn from cotton fabric had the highest particle retention rate, and that moreover, washing supported this effect.

\section{Study Limitations}

Lack of other evaluations such as biological load test and pressure test included in the mask effectiveness test constituted the limitations of our study. This study was designed to evaluate particle permeability. Universal indicators that should be in an effective mask are ability to filter microorganisms in both inhaled and exhaled air, being easy to breathe with mask, not being allergic, providing comfort for the wearer, being washable and cheap ${ }^{[22,23]}$. However, masks' ability to catch droplets and aerosols has come to the fore during the pandemic period. For this reason, the tests have concentrated on this issue.

\section{Conclusion}

In this study, it was shown that wearing two masks was superior to wearing a single mask. Using two medical masks together or a medical mask over or a fabric mask was found to be more effective than wearing either one alone. The most important outcome and widespread effect of this research will be the preference of cotton fabrics that capture the particles in the most effective way while choosing masks made of washable fabrics in the society and the dissemination of this knowledge.

\section{Acknowledgements}

Thanks to Mr. Dr. Burçak Çabuk, the Turkish Ministry of National Defense, Head of Chemical Biological Radiological Nuclear Defense Department, and Mr. Ali Şahin, Mechanical Chemical
Industry Corporation Maksam Machinery and Mask Factory Deputy Manager in assisting our institution in performing particle permeability tests.

\section{Ethics}

Ethics Committee Approval: Ethical committee approval is not required.

Informed Consent: Not necessary.

Peer-review: Internally peer-reviewed.

\section{Authorship Contributions}

Surgical and Medical Practices: A.K., Ö.G.T., S.B., B.B., F.B., Ü.M., P.A.Y., S.Ö., M.D., Concept: A.K., Ö.G.T., P.A.Y., S.Ö., M.D., M.N.İ, Design: A.K., Ö.G.T., M.D., Data Collection or Processing: A.K., Ö.G.T., Analysis or Interpretation: A.K., M.N.I., Literature Search: A.K., Ö.G.T., Writing: A.K., Ö.G.T., M.D., M.N.i.

Conflict of Interest: No conflict of interest was declared by the authors.

Financial Disclosure: The authors declared that this study received no financial support.

\section{References}

1. Centers for Disease Control and Prevention (CDC). Coronavirus disease (COVID-19): infection control guidance. Last Accessed Date: 29.03.2021. Available from: https://www.cdc.gov/coronavirus/2019-ncov/hcp/

2. World Health Organization (WHO). Infection prevention and control during health care when novel coronavirus (nCoV) infection is suspected. Last Accessed Date: 29.03.2021. Available from: https://www.who.int/ publications-detail/infection-prevention-and-control-during-health-carewhen-novel-coronavirus-(ncov)-infection-is-suspected

3. Kalkancı A, Baş S, Bostan B, Bay F, Metin Ü, Özden G, Güzel Tunçcan Ö, Özger S, Dizbay M. COVID-19 pandemi döneminde sağlık çalışanlarında kişisel koruyucu ekipman yönetimi: Gazi Üniversitesi Hastanesi Enfeksiyon Kontrol Komitesi uygulamaları. Gazi Med J 2020;31:309-15.

4. Kırman C. Yüz maskeleri, TMMOB Tekstil Mühendisleri Odası, Covid 19 Krizi Dönemi, Genel Bilgilendirme, Nisan 2020. Son Erişim Tarihi: 29.03.2021. Erişim Adresi: https://www.tmo.org.tr/images/ editorimages/Y\%C3\%9CZ\%20MASKELER\%C4\%B0\%20GENEL\%20 B\%C4\%BOLG\%C4\%BOLEND\%C4\%BORME.pdf

5. Centers for Disease Control and Prevention (CDC). Use masks to slow the spread of COVID-19. Last Accessed Date: 29.03.2021. Available from: https://www.cdc.gov/coronavirus/2019-ncov/prevent-getting-sick/diycloth-face-coverings.html

6. World Health Organization (WHO). Mask use in the context of COVID-19 Last Accessed Date: 12.04.2021. Available from: https://www.who.int/ publications/i/item/advice-on-the-use-of-masks-in-the-communityduring-home-care-and-in-healthcare-settings-in-the-context-of-thenovel-coronavirus-(2019-ncov)-outbreak

7. T.C. Sanayi ve Teknoloji Bakanlığı Türk Standartları Enstitüsü: Tekstilden mamul tekrar kullanılabilir koruyucu yüz maskeleri - Tıbbi olmayan. TSE K 599. Son Erişim Tarihi: 29.03.2021. Erişim Adresi: https://statik.tse.org.tr/ upload//tr/dosya/duyuruyonetimi/5919/11052020192406-2.pdf

8. Darby $\mathrm{S}$, Chulliyallipalil $\mathrm{K}$, Przyjalgowski M, McGowan $\mathrm{P}$, Jeffers $\mathrm{S}$, Giltinan A, Lewis L, Smith N, Sleator RD. COVID-19: mask efficacy is dependent on both fabric and fit. Future Microbiol. 2021;16:5-11. 
9. Centers for Disease Control and Prevention. Improve how your mask protects you. Last Accessed Date:29.03.2021. Available from: https://www. cdc.gov/coronavirus/2019-ncov/your-health/effective-masks.html

10. Howard J, Huang A, Li Z, Tufekci Z, Zdimal V, van der Westhuizen HM, von Delft A, Price A, Fridman L, Tang LH, Tang V, Watson GL, Bax CE, Shaikh R, Questier F, Hernandez D, Chu LF, Ramirez CM, Rimoin AW. An evidence review of face masks against COVID-19. Proc Natl Acad Sci U S A. 2021;118:e2014564118.

11. Cheng VC, Wong SC, Chuang VW, So SY, Chen JH, Sridhar S, To KK, Chan JF, Hung IF, Ho PL, Yuen KY. The role of community-wide wearing of face mask for control of coronavirus disease 2019 (COVID-19) epidemic due to SARSCoV-2. J Infect. 2020;81:107-14.

12. Chughtai AA, Seale $H$, Macintyre CR. Effectiveness of cloth masks for protection against severe acute respiratory syndrome coronavirus 2. Emerg Infect Dis. 2020;26:e200948.

13. Rengasamy S, Eimer B, Shaffer RE. Simple respiratory protection-evaluation of the filtration performance of cloth masks and common fabric materials against 20-1000 nm size particles. Ann Occup Hyg. 2010;54:789-98.

14. Ho KF, Lin LY, Weng SP, Chuang KJ. Medical mask versus cotton mask for preventing respiratory droplet transmission in micro environments. Sci Total Environ. 2020;735:139510.

15. Fischer EP, Fischer MC, Grass D, Henrion I, Warren WS, Westman E. Low-cost measurement of face mask efficacy for filtering expelled droplets during speech. Sci Adv. 2020;6:eabd3083.

16. Swain ID. Why the mask? The effectiveness of face masks in preventing the spread of respiratory infections such as COVID-19 - a home testing protocol. J Med Eng Technol. 2020;44:334-7.
17. Furuhashi M. A study on the microbial filtration efficiency of surgical face masks--with special reference to the non-woven fabric mask. Bull Tokyo Med Dent Univ. 1978;25:7-15.

18. Douglas JDM, McLean N, Horsley C, Higgins G, Douglas CM, Robertson E. COVID-19: smoke testing of surgical mask and respirators. Occup Med (Lond). 2020;70:556-63.

19. T.C. Sağıık Bakanlığı, COVID-19 Salgın Yönetimi ve Çalışma Rehberi, Bilimsel Danışma Kurulu Çalışması, 1 Ekim 2020. Son Erişim Tarihi: 29.03.2021. Erişim Adresi: https://covid19.saglik.gov.tr/Eklenti/40340/0/covid-19salgin yonetimivecalismarehberipdf.pdf

20. Hill WC, Hull MS, MacCuspie RI. Testing of commercial masks and respirators and cotton mask insert materials using SARS-CoV-2 virion-sized particulates: Comparison of ideal aerosol filtration efficiency versus fitted filtration efficiency. Nano Lett. 2020;20:7642-7.

21. Zangmeister $C D$, Radney JG, Vicenzi EP, Weaver JL. Filtration efficiencies of nanoscale aerosol by cloth mask materials used to slow the spread of SARSCoV-2. ACS Nano. 2020;14:9188-200.

22. Beesoon S, Behary N, Perwuelz A. Universal masking during COVID-19 pandemic: Can textile engineering help public health? Narrative review of the evidence. Prev Med 2020;139:106236.

23. World Health Organization. Advice on the use of masks in the community setting in influenza A (H1N1) outbreaks. Last Accessed Date: 29.03.2021. Available from: http://www.who.int/csr/resources/publications/swineflu/ masks_community/en/index.html 